\section{Nordic countries urged to boost internal cooperation}

Lund, Sweden. Last month's entry into force of the European Economic Area (EEA) agreement between the 12 countries of the European Union (EU) and six countries of the European Free Trade Association (EFTA) means that all five

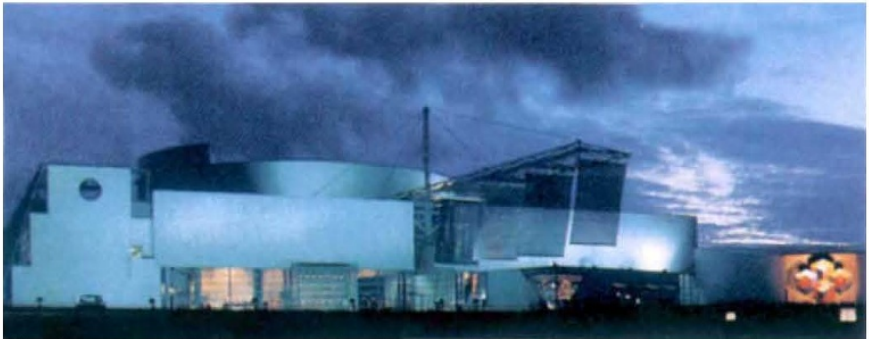
Northern enlightenment: Finland's Heureka science centre.
Nordic countries (and Austria) are now able to participate fully in the EU's research programmes.

But a conference held here last week of the Nordic council of ministers (NCM) for education and research showed that their efforts to find a common political vision under these new circumstances are being hampered by economic difficulties, and by uncertainty over the adhesion of Sweden, Finland and Norway to the EU.

The Nordic countries - Denmark, Finland, Iceland, Norway and Sweden - are particularly concerned that the shift towards Europe may diminish inter-Nordic cooperation. "Are we going to continue [the NCM] or are we going to write it off?" asks Ole Vig Jensen, the Danish minister for education.

Nordic politicians have long sought closer regional cooperation, and indeed set an example by establishing freedom of movement between their countries in the $1950 \mathrm{~s}$. In the fields of science and education, the council has established a number of joint research institutes, postgraduate training schemes and scientific networks.

Furthermore, from the next academic year, students living in one Nordic country will be entitled to receive higher education in another country under conditions identical to those at home.

"The Nordic countries cannot assert themselves internationally if they do not work together," Per Unckel, the Swedish science

minister, told the meeting. He added that continued cooperation was particularly needed to boost the quality of Nordic research in order to improve the poor record of the region in attracting foreign researchers.

Another incentive to cooperation is that the Nordic countries are keen to preserve their egalitarian model of society, and indeed to export aspects of it to the EU. Antonio Ruberti, for example, the EU's research commissioner, told the conference that the EU could learn from their more advanced education and training systems.

But, as one observer at the meeting put it "inter-Nordic cooperation has been based on negotiating different viewpoints, and we can't expect them to express a single viewpoint to Europe". National preoccupations may also increase because subscriptions to EU programmes will reduce the money available for both national and Nordic programmes.

Moreover, discussions about interNordic cooperation in research have taken a back seat in several Nordic countries to the immediate problems caused by the end of decades of economic growth, and the switch from a welfare state to a free market philosophy (see Nature 360, 509; 1993).

For example, Riita Uosukainen, the Finnish minister for education, said that the economic difficulties faced by her country restricted her political vision to making cuts with the least damage. "There's not much else I can do."

Declan Butler

\section{Launch success marks Japan's space debut}

Tokyo. Officials of Japan's National Space Development Agency gave a collective sigh of relief last week after the flawless launch of the H-II rocket, the first launch vehicle to be made entirely in Japan.

Development of the H-II's sophisticated first-stage engine has been plagued with problems and delays. But, apart from a few days' delay caused by bad weather and a minor technical problem, the launch went perfectly. The rocket placed two payloads in orbit, one being a re-entry vehicle that splashed down by parachute a few hours later in the Pacific Ocean, having orbited

\section{the Earth before doing so}

The successful launch ends the agency's dependency on US rocket technology and opens the way for Japan to compete in the commercial launch market. After the launch, Satskui Eda, the director-general of the Science and Technology Agency, denied that Japan's rocket development programme was intended to help turn the country into a major military power, and claimed that it would help turn space from a theatre for military competition into a sphere of activity "for people who want to give wings to peaceful dreams". David Swinbanks
London. Britain's Sunday Times appears to have backed off from its self-styled campaign to question the relationship between HIV and AIDS. So far this year, the newspaper has published only one feature article about AIDS (on 30 January), and this was a story that had already been reported extensively last year about a woman who is suing Wellcome over her husband's treatment with the antiretroviral drug AZT.

The recent lack of stories compares with the 25 - making an average of one story every two weeks - published by the newspaper during 1993. Most of these were intended to raise questions about the scientific validity of claims about the causal relationship between HIV and AIDS, and to cast doubt on the severity of AIDS epidemics in Africa.

The apparent cooling off in the Sunday Times campaigns follows a bold declaration of its "refusal to be silenced" on the issue in mid-December 1993. But by 6 January, readers wishing to join the debate were being sent letters saying that the correspondence was being closed.

Meanwhile, the position of the Sunday Times on AIDS in Africa continues to be challenged both by reports in the scientific literature documenting the continued spread of the disease, and by anecdotal reports from African countries (see Nature 367, 103; 1994).

For example, a large collaborative study from US and Ugandan researchers, published by the British Medical Journal in its issue of 15 January concludes that the incidence of HIV infection remains high in rural areas of Uganda, and argues that prevention strategies are urgently needed in the country.

The most recent journalistic investigation of claims by the Sunday newspaper that the spread of AIDS in Africa is a "myth" was a radio item broadcast by the $B B C$ on 6 February as part of its midday current affairs programme The World this Weekend.

The programme featured an interview with Philippe Krynen, a French charity worker whose views form the central plank of the argument developed by the Sunday Times that there is no AIDS epidemic in Africa.

Krynen told the interviewer that he took pride in not being medically qualified, as this meant he was able to make up his own mind about the extent of AIDS in Africa. But his views contrasted sharply with those of a large number of doctors and other medical workers interviewed on the programme.
Maxine Clarke 